\title{
Search for Authentic Existence in Anita Desai's Novel the Zigzag Way
}

\author{
Priyanka Aggarwal \\ Research Scholar, Department of English, \\ Mewar University, Chittorgarh, Rajasthan, India \\ priyankamittal7777@gmail.com \\ Prof. J. C. Batra \\ Department of English, \\ O.P. Jindal Global University, Sonepat, Haryana, India
}

\begin{abstract}
This paper attempts to search for the philosophy of existentialism in the novel The Zigzag Way written by Indian's leading novelist Anita Desai. Despite the horde of tensions implanted in the mysterious colors and the violent history of the past and reality of the present, Desai gets to locate the specific existential strand of authentic existence in this novel. History gets in to the novel inconspicuously, meandering between different social and cultural consciousnesses. Her thrilling new novel showcases her unique ability to view an entirely new world which is totally un-Indian except for the similarity of the name of the aborigine tribe: Indians. Desai has proved that she can tackle an entirely alien terrain with as much felicity as she evinces while taking up the Indian locale, characters and themes.
\end{abstract}

Keywords : Compassion, Haunting atmosphere, Mystery, Myth, Dark violence.

\section{INTRODUCTION}

In The Zigzag Way (2005), she draws a miniaturist portrait of the twentieth-century Mexico as experienced by a young American man Eric. He has come to Mexico as first- time tourist though his wife is on a study mission. With vivid sympathy and giving details, Desai evokes Eric's grandparents and their community. At first, overcome by sensory overload, he is gradually seduced by the strangeness, the colors and the mysterious of an ancient world. He finds himself on a curious quest for his own family in an old mining town where a hundred years earlier young Cornish miners toiled without any relief. The novel focuses on the history of Mexico's silver mines, where a large numbers of Cornish miners were employed. The places they lived in are now ghost towns. The formidable queen of the Sierra, 'Dona Vera', widow of a mining baron who suffers the same pain with a colorful dubious, European past. At the feast of the day of the dead, when the locals celebrate and remember their departed, the zigzag paths of their lives converge, bringing together past and present in a moment of powerful epiphany.

The Zigzag Way is a magical novel of elegiac beauty with mysterious and disturbing splashes of highspirited color and darker violence. Inspired with history, compassion and sense of wonder, Desai's advanced and affecting novel is ravishing all around. Strongly it evokes a distant time and place. Desai has undoubtedly woven together the threads of history and present life which affect the lives and identity of people. It is a history from the writer's point of view that tries to discover suppressed or neglected chapters of a society and its culture. Milan Kundera has observed about this aspect:

"History is in a position similar to the poet's own. History does not invent, it discovers. Though new situations, History reveal what man is, what has been in him 'for a long time, what his possibilities are?' (Kundera 115)

Desai's novel The Zigzag Way is set in Mexico and Cornwall, in which Desai has uncovered a compelling chapter in Mexican history. Eric is a newly minted historian just out of graduate school, unsure of his future. With no clear direction, he follows his lover, Em, when she travels to the Yucatan for her scientific research, but he ends up alone in the foreign place. And so he pursues his own private quest, tracing his family's history to a Mexican ghost town, where a hundred years 
earlier, young Cornish miners toiled to the death. Very sympathetically, Desai depicts the struggles of Eric's grandparents and their community.

From his glimpse of Popocatepetl from the plane, Eric is enraptured by the exotic country. While Em works, he explores Mexico City, and one afternoon he wanders into a lecture about the Huichol Indians. Unfortunately for Eric, the lecturer, an elderly woman wearing "an extraordinary extravagant costume," speaks primarily in Spanish, but suddenly he begins to recognize certain words.

"Eric was later to describe the experience, to Em, as like stumbling into a rabbit hole-falling, falling, he said, till all was a welter of strange words, strange names churning around him. Then, with a bump, landing upon the startling awareness that many of them were actually familiar to him" (31).

Dona Vera, he learns presently, has departed from her advertised subject to describe the way the mines have devastated Indian lands. Eric recognizes the names from his one visit, as a small boy, to his grandparents in Cornwall when his grandfather Davey described the years he had spent working in the mines of Mexico. When Em heads off to the Yucatan to pursue her research into malaria, Eric travels into the Sierra Madre in a vague attempt to find some remnants of his own past.

But the novel does not follow only Eric. Desai has a remarkable gift for compression, and the second section explores the life of Dona Vera, the lecturer, who managed to leave Germany during the Second World War by marrying into a Mexican mining family, and who subsequently reinvented herself as an expert on the Huichol Indians. The exquisite third section is devoted to Eric's grandmother Betty, who in 1910 made the long voyage from Cornwall to Mexico to marry Davey. Full of ardor and curiosity, Betty sets up house in a small mining town where Davey and the other Cornish miners work, only to find her life painfully circumscribed. She is unable to leave the house on Sundays because of the drunken brawls.

Davey does not like her going to the local market, even with their maid, Lupe. When she buys cheap earthenware from the local potter, both Davey and Lupe disapprove. It is surely no accident that both Vera and Davey come to Mexico out of necessity, unlike Eric, who is a leisurely tourist. The complexities of forced immigration and the exploitation of workers, migrant and otherwise, are certainly part of Desai's larger theme, but so is something deeper, darker, and more ancient.

The novel opens with Eric arriving at an inn near the mining town where his grandparents lived. Waiting in the candlelit hall, he looks up to see "a skull with green sequins for eyes and a circlet of gilt marigolds for a crown. Above this, on the wall, all skeletons danced and cavorted, rustling in the draught from the door, for they were cut out of paper" (4). Throughout these pages both the characters and the reader confront images of death and of the relationship-mysterious, tenacious, elusivebetween the living and the dead.

A chance encounter in a bookshop in Mexico City triggers Eric's memory at the beginning of this novel by Anita Desai. With a start, he is taken back to a moment in a childhood, to a visit to his grandparents and a toy train filled with tiny nuggets of gold. He can recall very little else: an elderly man smoking a pipe, and a list of names- Valenciana, Los Lorenzos, Sierra Madre Oriental- "that made the boy tingle as if the pins and needles in his knees had spread all through him". But that flash of "re-cognition" is enough to make him set off into the Sierra Madre Oriental Mountains to the northeast of Mexico City. His grandmother, a miner's wife who had emigrated from Cornwall in search of gold, died in childbirth amid those mountains.

The brief final section of the novel shows Eric joining the celebration of La Noche de losMuertos at the grave yard where his grandmother is buried. But the title of the novel, and indeed Eric's own youthful nature, suggest another major theme. When Em refuses him to accompany to the Yucatan, Eric "looked at her and smiled... How foolish to think he could join the company of the sure and the certain, those who knew what to do with themselves from morning to night everyday of the year and everywhere"(26). For Eric the major questions are to do with life and the conduct there of, not death, and later at Dona Vera's hacienda, when he reads an account of how the Indian porters in the mines used to ascend in a zigzag fashion, he recognizes his own privileged journey.

Now, in place of the Cornish workers, the native Huichol Indians suffer the cruelty of the mine owners. When he enquires into their lives, Eric provokes the ire of their self-appointed savior Dona Vera, known as the queen of the Sierra 'seated by an empty fireplace in a wing chair, with her pugs' (54). Dona Vera is the widow of a mining baron who has dedicated her fortune to preserve the Huichol culture. But her formidable presence belies a dubious past. 
The zigzag paths of these characters converge on the Day of the Dead, bringing together past and present in a moment of powerful epiphany. Eric learns from an inn-keeper that people come on the occasion of the festival Dia de los Muertos, to pay homage to the dead relatives.

He sets out to visit the mining area. He has no idea of the grave of his grandmother but the intensity of his passion results in a mystical meeting with her apparition. Anita Desai is known for keeping the veil of mystery intact and so, contrary to the common belief in the omniscience of souls, this grandmother's apparition mistakes him for Paul (his father). The veracity of the apparition is supported by the author thus:

A young woman was descending it, with such ease and speed it was as though she did not notice the stones in her way, they were not impediments to her. She was preceded by a fragrance that was as fresh as the breeze that was blowing freely, not the heavy perfume of copal, tallow candles and funeral flowers but a much lighter, more natural one, of herbs like lavender, rosemary and thyme, mountain herbs that seemed unlikely to be growing in that hostile rubble and stoniness but perhaps were since their essence was clearly present (175).

Seeing Eric standing by the low wall that ringed the cemetery, she lifted her hand, holding a small bunch of grey leaves and pale flowers, and to his amazement, waved to him. He could not imagine why she acknowledged him or who she might be or why she was there, but his mind had ceased to pose questions, they were all obliterated by the wave of her hand and the pure scent of the flowers (175).

Eric and the ghost of her grandmother have a lengthy discussion about sundry things, among them about the cactus plants, the Indian pilgrims visiting the place, Eric's grandfather's family origin etc. Finally, the unreality of the ghost is revealed when she beckons Eric to follow her but he cannot get through the wall like the ghost does and misses her trail altogether in the light of the dawn. Nevertheless, he has succeeded in paying homage to his ancestors and locating the missing link in building his identity. According to a critic, "Their conception of their authentic life is not conditioned by any social ideology, creed or religion. The calling comes from within. The obstacles en route their quest is a plenty and the end result is failure by worldly standards. But they have taken their own decisions and would not blame others. There is no whining and whimpering on their part. They are heroes and heroines of modern day epics called life" (Batra 52).

\section{CONClusion}

Thus The Zigzag Way is an unfashionably quiet novel, in which history and landscape are more important than characters. It is seen that by and large, Desai's characters, pursue different goals physical security, individual privacy, following a dream with the zeal of a zealot.

\section{REFERENCES}

[1] Desai, A. (2005). The Zigzag Way. London: Vintage (Chatto and Windus).

[2] Kundera, M. (1986). The Art of Novel. Trans. Linda Asher. Calcutta: Rupa and Co.

[3] Batra, J. (2011). Quest for Authentic Existence in Anita Desai, The Atlantic Literary Review, Vol. 12, No. 4.

\section{AUTHORS' BIOGRAPHY}

Priyanka Aggarwal, research Scholar of Mewar University, Rajasthan. She has more than twelve years of teaching experience. She has presented papers at many national and international conferences and published widely.

Prof. (Dr.) Jagdish Batra, Professor Emeritus of English, JJT University (Rajasthan) is currently Jt. Director, English Language Centre, O.P. Jindal Global University at Sonepat (India). He has more than thirty years of teaching experience. Dr Batra has served as a resource person and presented papers at many national and international conferences and published widely. Besides, he has guided six Ph.D. and thirty-one M. Phil candidates. His main area of research is Indian English Fiction. Dr. Batra has written half-a-dozen books covering subjects like Rohinton Mistry, Jhumpa Lahiri, Indian English Fiction, T.S. Eliot and Critical theory 